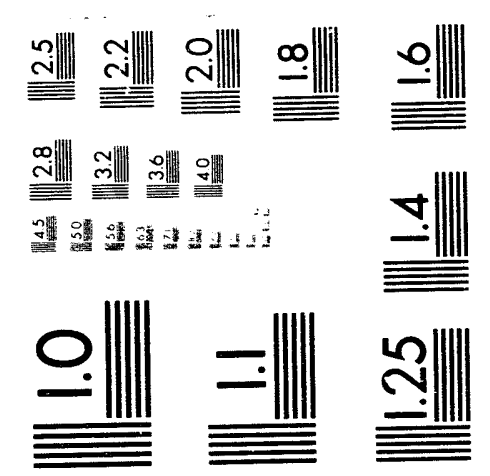



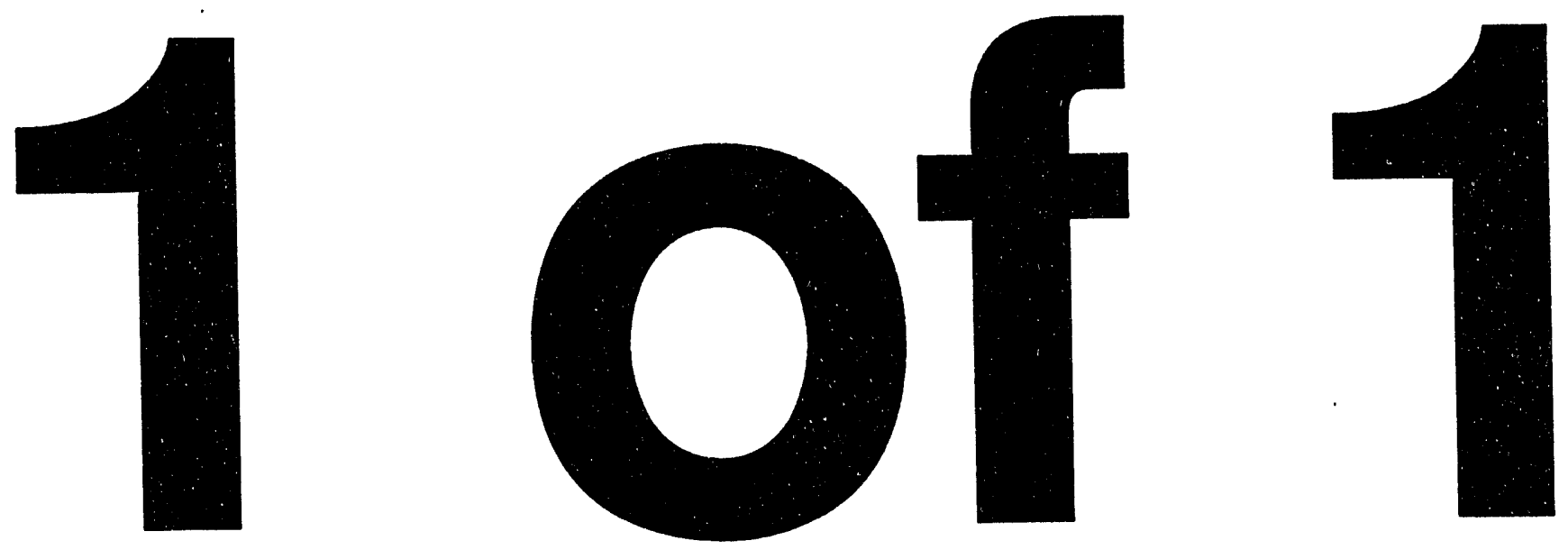


\section{Derivation of Uranium Residual Radioactive Material Guidelines for the Former Alba Craft Laboratory Site, Oxford, Ohio}

by M. Nimmagadda, E. Faillace, and C. Yu

Environmental Assessment Division,

Argonne National Laboratory, 9700 South Cass Avenue, Argonne, Illinois 60439

January 1994

Work sponsored by United States Department of Energy 


\section{CONTENTS}

NOTATION $\ldots \ldots \ldots \ldots \ldots \ldots \ldots \ldots \ldots \ldots \ldots \ldots \ldots \ldots \ldots \ldots \ldots$

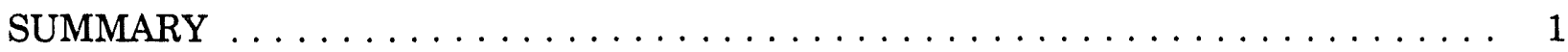

1 INTRODUCTION AND BRIEF HISTORY $\ldots \ldots \ldots \ldots \ldots \ldots \ldots$

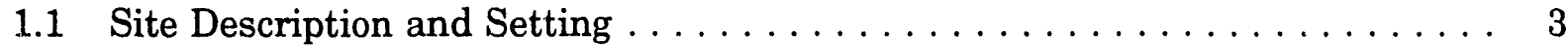

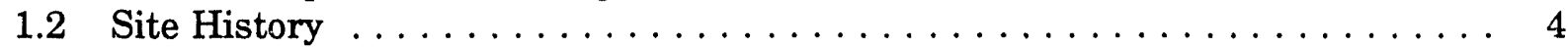

1.3 Derivation of Cleanup Guidelines $\ldots \ldots \ldots \ldots \ldots \ldots \ldots$

2 SCENARIO DEFINITIONS $\ldots \ldots \ldots \ldots \ldots \ldots \ldots \ldots \ldots \ldots \ldots$

3 DOSE/SOURCE CONCENTRATION RATIOS $\ldots \ldots \ldots \ldots \ldots \ldots \ldots \ldots$

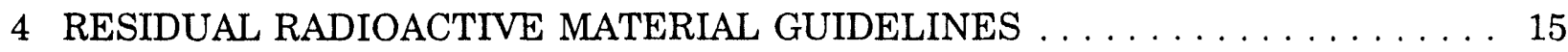

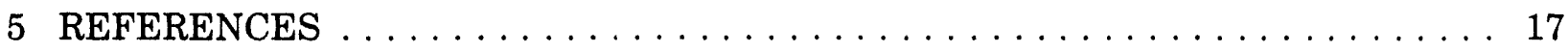

APPENDIX: Scenarios and Parameters Used for the Analysis

of the Former Alba Craft Laboratory Site . . . . . . . . . . . . . . . 18

\section{FIGURES}

1 Location of the Former Alba Craft Laboratory Site, Oxford, Ohio . . . . . . . 4

2 Map of the Former Alba Craft Laboratory Site $\ldots \ldots \ldots \ldots \ldots \ldots$

\section{TABLES}

1 Summary of Pathways for Scenarios A, B, and C at the Former Alba Craft Laboratory Site $\ldots \ldots \ldots \ldots \ldots \ldots \ldots \ldots \ldots \ldots$

2 Maximum Dose/Source Concentration Ratios for Scenario A at the Former Alba Craft Laboratory Site . . . . . . . . . . . . . . . . . . . . . 12

3 Maximum Dose/Source Concentration Ratios for Scenario B at the Former Alba Craft Laboratory Site . . . . . . . . . . . . . . . . . . 12

4 Maximum Dose/Source Concentration Ratios for Scenario $\mathrm{C}$ at the Former Alba Craft Laboratory Site . . . . . . . . . . . . . . . . . . . . 13

5 Total Dose/Source Concentration Ratios for Uranium at the Former Alba Craft Laboratory Site 


\section{TABLES (Cont.)}

6 Residual Radioactive Material Guidelines for the Former Alba Craft Laboratory Site . . . . . . . . . . . . . . . . . . . . . . 15

7 Ranges for Hot Spot Multiplication Factors $\ldots \ldots \ldots \ldots \ldots \ldots$

A.1 Parameters Used in the RESRAD Computer Code for the Analysis of the Former Alba Craft Laboratory Site . . . . . . . . . . . . . . . . . . . . . . 19 


\section{NOTATION}

The following is a list of the acronyms, initialisms, and abbreviations (including units of measure) used in this document. Some acronyms used in tables or equations only are defined in the respective tables or equations.

\section{ACRONYMS, INITIALISMS, AND ABBREVIATIONS}
AEC
U.S. Atomic Energy Commission
ALARA as low as reasonably achievable
DOE U.S. Department of Energy
FUSRAP Formerly Utilized Sites Remedial Action Program
MED Manhattan Engineer District
NLO National Lead of Ohio
ORNL Oak Ridge National Laboratory
RESRAD residual radioactive material guideline computer code

\section{UNITS OF MEASURE}

$\begin{array}{ll}\mathrm{cm} & \text { centimeter(s) } \\ \mathrm{cm}^{3} & \text { cubic centimeter(s) } \\ \mathrm{d} & \text { day(s) } \\ \mathrm{g} & \text { gram(s) } \\ \mathrm{h} & \text { hour(s) } \\ \mathrm{kg} & \text { kilogram(s) } \\ \mathrm{L} & \operatorname{liter}(\mathrm{s})\end{array}$

$\begin{array}{ll}\mathrm{m}^{2} & \text { meter(s) } \\ \mathrm{m}^{2} & \text { square meter(s) } \\ \mathrm{m}^{3} & \text { cubic meter(s) } \\ \mathrm{mrem} & \text { millirem(s) } \\ \mathrm{pCi} & \text { picocurie(s) } \\ \mathrm{s} & \text { second(s) } \\ \mathrm{yr} & \text { year(s) }\end{array}$




\title{
DERIVATION OF URANIUM RESIDUAL RADIOACTIVE MATERIAL GUIDELINES FOR THE FORMER ALBA CRAFT LABORATORY SITE, OXFORD, OHIO
}

\author{
by
}

M. Nimmagadda, E. Faillace, and C. Yu

\section{SUMMMARY}

Residual radioactive material guidelines for uranium were derived for the former Alba Craft Laboratory site in Oxford, Ohio. This site has been identified for remedial action under the Formerly Utilized Sites Remedial Action Program (FUSRAP) of the U.S. Department of Energy (DOE). Single nuclide and total uranium guidelines were derived on the basis of the requirement that the 50-year committed effective dose equivalent to a hypothetical individual who lives or works in the immediate vicinity of the former Alba Craft Laboratory site should not exceed a dose of $30 \mathrm{mrem} / \mathrm{yr}$ following remedial action for the current use and likely future use scenarios or a dose of $100 \mathrm{mrem} / \mathrm{yr}$ for less likely future use scenarios ( $\mathrm{Yu}$ et al. 1993). The DOE residual radioactive material guideline computer code, RESRAD, which implements the methodology described in the DOE manual for implementing residual radioactive material guidelines, was used in this evaluation.

Three potential scenarios are considered in which it is assumed that, for a period of 1,000 years following remedial action, the site will be used without radiological restrictions. The three scenarios vary with regard to the type of site use, time spent at the site, and sources of food consumed. The results of the evaluation indicate that the basic dose constraint of $30 \mathrm{mrem} / \mathrm{yr}$ will not be exceeded for uranium (including uranium-234, uranium-235, and uranium-238) within 1,000 years, provided that the soil concentration of total combined uranium (uranium-234, uranium-235, and uranium-238) at the former Alba Craft Laboratory site does not exceed the following levels: $770 \mathrm{pCi} / \mathrm{g}$ for Scenario A (industrial worker: current use scenario) and $280 \mathrm{pCi} / \mathrm{g}$ for Scenario B (resident: municipal water supply, a likely future use scenario). The basic dose limit of $100 \mathrm{mrem} / \mathrm{yr}$ will not be exceeded at the site if the total uranium concentration does not exceed the level of $310 \mathrm{pCi} / \mathrm{g}$ for Scenario C (resident: on-site well water, a plausible but unlikely future use scenario).

The uranium guidelines derived in this analysis apply to the total activity concentration of uranium isotopes, i.e., uranium-238, uranium-234, and uranium-235 present in their natural activity concentration ratio of $1: 1: 0.046$. Consequently, if uranium-238 were measured as the indicator radionuclide, the respective limits for Scenarios A, B, and C would be 380,140 , and $150 \mathrm{pCi} / \mathrm{g}$, respectively. These guidelines were calculated on the basis of a dose of $30 \mathrm{mrem} / \mathrm{yr}$ for Scenarios A and B and a dose of $100 \mathrm{mrem} / \mathrm{yr}$ for Scenario C (Yu et al. 1993). In setting the actual uranium guidelines for the former Alba Craft Laboratory site, 
DOE will apply the as low as reasonably achievable (ALARA) policy to the decision-making process, along with other factors such as whether a particular scenario is reasonable and appropriate. 


\section{INTRODUCTION AND BRIEF IISTORY}

The former Alba Craft Laboratory, Incorporated, is located in Oxford, Ohio (Figure 1). The site has been designated by the U.S. Department of Energy (DOE) as a candidate for remedial action undes its Formerly Utilized Sites Remedial Action Program (FUSRAP). This designation was made after a preliminary inspection by Oak Ridge National Laboratory (ORNL) in June 1992 indicated that uranium contamination is present both inside and outside the Alba Craft building. FUSRAP was established in 1974 by the U.S. Atomic Energy Commission (AEC), a predecessor of DOE. The mandate of the program is to identify, evaluate, and, if necessary, decontaminate sites previously used by the AEC or its predecessor, the Manhattan Engineer District (MED).

Remedial action activities at the former Alba Craft Laboratory site will follow the guidelines established in DOE Order 5400.5 (DOE 1990). The DOE residual radioactive material computer code, RESRAD (Yu et al. 1993), is used to derive residual radionuclide guidelines on a site-specific basis. This report presents the uranium guidelines derived for the former Alba Craft Laboratory site on the basis of a dose constraint of $30 \mathrm{mrem} / \mathrm{yr}$ for the current use and likely future use scenarios and a dose limit of $100 \mathrm{mrem} / \mathrm{yr}$ for less likely but plausible future use scenarios (Yu et al. 1993). The dose constraint of $30 \mathrm{mrem} / \mathrm{yr}$ is not currently required under DOE Order 5400.5. However, DOE is proposing to reduce the existing limit of $100 \mathrm{mrem} / \mathrm{yr}$ on the basis of recommendations from the International Commission on Radiological Protection (1991).

\subsection{SITE DESCRIPTION AND SETTING}

The Alba Craft Laboratory site is occupied by a building that consists of three separate structures that have been joined to appear as one building. At the time of the ORNL radiological survey, the building was being used to support three independent businesses. The east wing contained a chemistry laboratory and supporting offices, the west wing was used to produce custom-embroidered products such as shirts and caps, and the north wing was leased to a contractor to store packaged foods (Murray et al. 1993). The building is surrounded on the east, north, and south sides by residential homes and apartments (Figure 2).

The town of Oxford is located in Butler County, Ohio. Hydrogeologic information for this area was obtained from Smith (1982). This information was used to characterize the contaminated zone, unsaturated zone, and saturated zone for the purpose of modeling contaminant transport in groundwater beneath the former Alba Craft Laboratory site because no boreholes have been drilled at the site. The topsoils and subsoils in the area typically extend to a depth of $2.4 \mathrm{~m}$ followed by layers of clay, sandy soil, sand and gravel, and blue clay. Interbedded limestones and shales of the Cincinnatian Series are present below a depth of $10 \mathrm{~m}$ and can extend to depths greater than $400 \mathrm{~m}$. These limestones and shales form an effective aquitard, and wells in the area tap the groundwater in the sand and gravel layers 


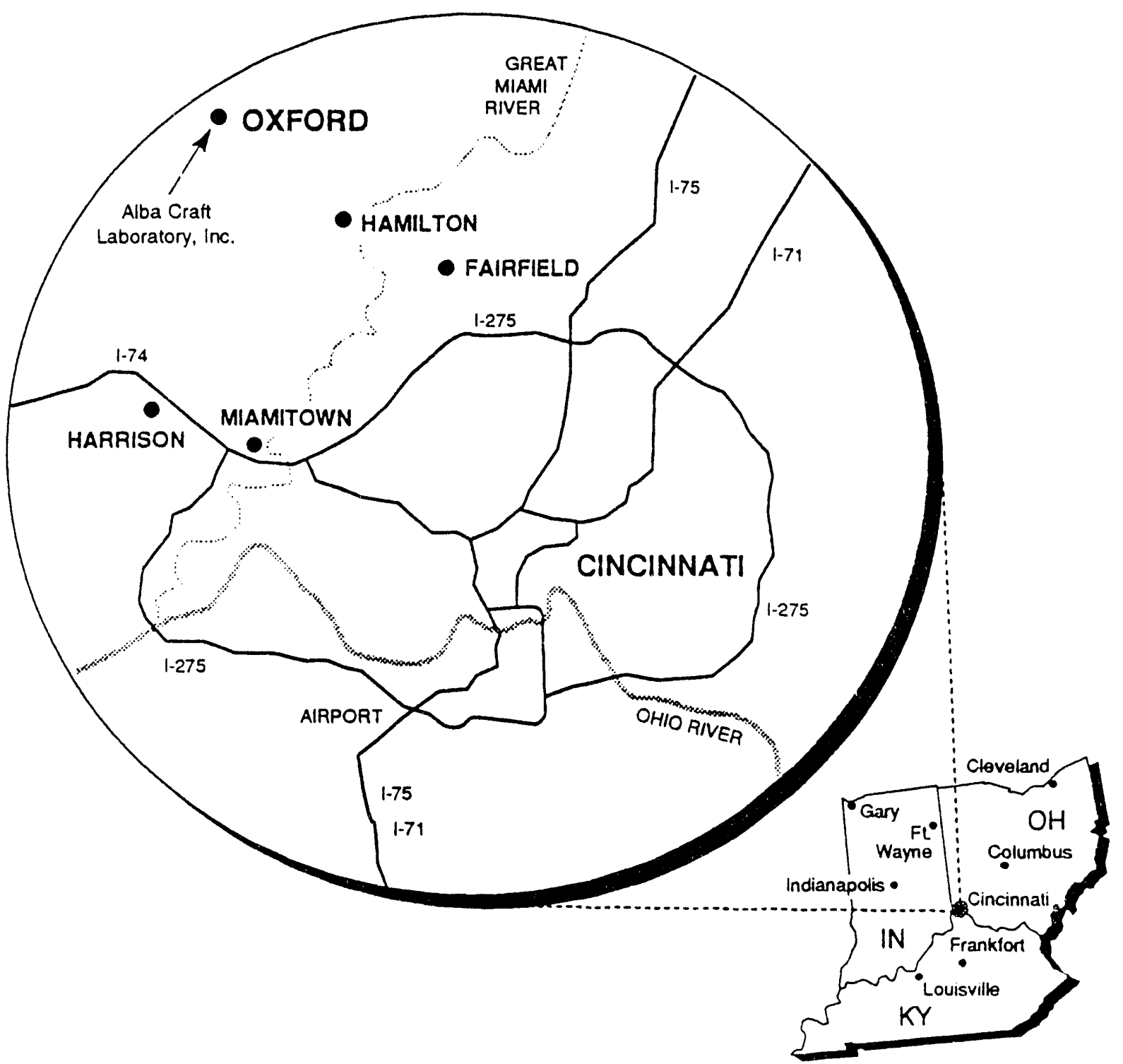

FIGURE 1 Location of the Former Alba Craft Laboratory Site, Oxford, Ohio (Source: Adapted from Murray et al. 1993)

located approximately 6 to $8 \mathrm{~m}$ below the surface (Smith 1982). The mean annual precipitation is about $103 \mathrm{~cm}$. The average annual runoff is about $21 \%$ of the average precipitation, and evapotranspiration is approximately $57 \%$ of the average precipitation (Smith 1982).

\subsection{SITE HISTORY}

Alba Craft Laboratory, Incorporated, was a subcontractor to National Lead of Ohio (NLO) from approximately October 1952 to February 1957. Alba Craft provided a variety of machine shop services on normal uranium metal for NLO, a primary contractor fur the AEC. 


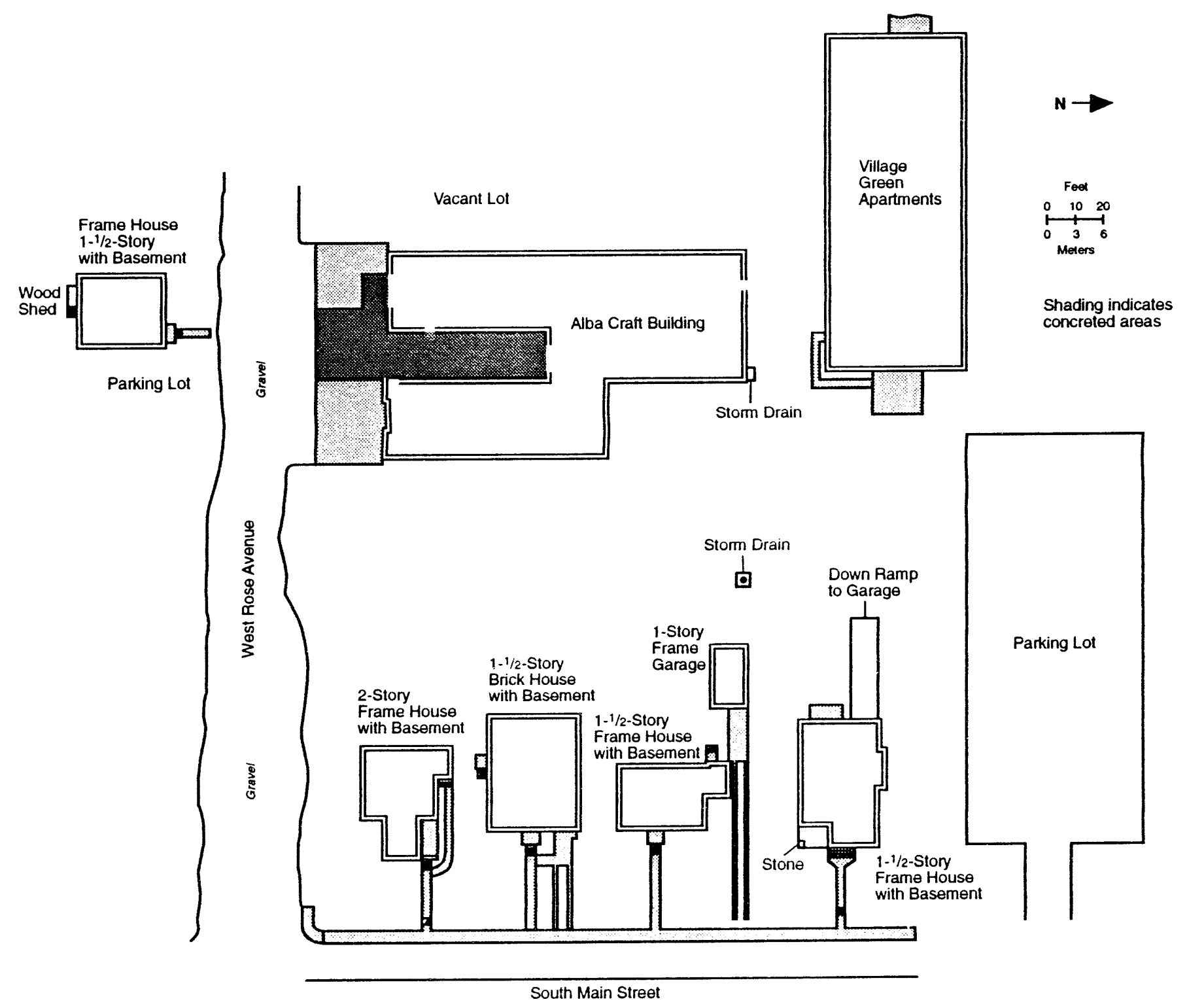

FIGURE 2 Map of the Former Alba Craft Laboratory Site (Source: Adapted from Murray et al. 1993) 
Early work included general machining and developmental machining of threaded slugs for the Savannah River Site in Aiken, South Carolina. Final operations were on a large production scale and consisted of hollow drilling and turning slugs for reactors at the Savannah River Site and the Hanford Site in Richland, Washington. In 1954, the Alba Craft facilities were also used by NLO, which supplied its own operators and material for machining. The total quantity of uranium machined by Alba Craft is estimated at several hundred tons; the quantity machined by NLO during 1954 is unknown.

As a result of the activities performed at the site, equipment, buildings, and land at some of the adjacent vicinity properties became contaminated with low levels of radioactive material. At contract termination, sites used by contractors were decontaminated in accordance with the standards and survey methods in use at that time. Since the original assessments, more stringent radiological criteria and guidelines have been implemented for the release of such sites for unrestricted use.

The current owner bought and renovated the building and began using it to support various business enterprises. The east wing has been remodeled with stud walls, a drop ceiling, and carpet. Little remodeling was performed on the west and north wings. The outside area between the east and west wings has been newly concreted and is used to provide access for deliveries (darker shaded area in Figure 2).

Previous investigations were conducted to determine the extent of on-site radioactive contamination. As a follow-up to these investigations and as a precaution to ensure that residual radioactive material exceeding current DOE guidelines did not migrate off-site, DOE requested a radiological survey of the former laboratory and vicinity properties. A preliminary inspection in June 1992 indicaied the presence of uranium contamination both inside and outside the former Alba Craft building.

In July and September 1992, a radiological survey was conducted at the former Alba Craft Laboratory building and vicinity properties. The results indicated that uranium contamination from former AEC-related activities still exists in and around the building in quantities exceeding current DOE guidelines (Murray et al. 1993). The contamination around the building extends onto some of the residential properties now located on the former Alba Craft site (Figure 2).

\subsection{DERIVATION OF CLEANUP GUIDELINES}

Although most DOE cleanup guidelines applicable to remedial actions at FUSRAP sites are generic in nature (DOE 1990), guidelines for uranium are derived on a site-specific basis. The purpose of this analysis was to derive the residual radioactive material guidelines for uranium (i.e., uranium-234, uranium-235, uranium-238, and total uranium) that are applicable to remedial action at the former Alba Craft Laboratory site. The derived guidelines represent the residual concentration of uranium in a homogeneously contaminated area that must not be exceeded if the site is to be released for use without radiological 
restrictions. The total uranium guideline is derived by assuming that uranium-238, uranium-234, and uranium-235 are present in their natural activity concentration ratio of $1: 1: 0.046$.

Site-specific uranium guidelines for the former Alba Craft Laboratory site were derived on the basis of a dose constraint of $30 \mathrm{mrem} / \mathrm{yr}$ for the current use and likely future use scenarios and a dose limit of $100 \mathrm{mrem} / \mathrm{yr}$ for less likely but plausible future use scenarios (Yu et al. 1993); it was assumed that uranium is the only radionuclide present at an above-background concentration. The RFSRAD computer code, version 5.03, was used to derive these guidelines. The RESRAD code is used to implement the methodology described in the DOE manual for implementing residual radioactive material guidelines ( $\mathrm{Yu}$ et al. 1993). 


\section{SCENARIO DEFINITIONS}

Three potential exposure scenarios were considered for the former Alba Craft Laboratory site. In these scenarios it was assumed that, at some time within 1,000 years, the site will be released for use without radiological restrictions following remedial action. All pathways considered for Scenarios A, B, and C are summarized in Table 1.

Scenario A (the current use scenario) assumes continued industrial use of the site. Under this scenario, a hypothetical individual is assumed to work in the area of the site for 8 hours per day ( 6 hours outdoors and 2 hours indoors), 5 days per week, 50 weeks per year. Therefore, in one year the industrial worker is assumed to spend $17 \%$ of the time working outdoors at the site; $6 \%$ of the time working indoors at the site; and $77 \%$ of the time away from the site. It is alio assumed that the worker does not ingest water, plant foods, or fish obtained from the decontaminated area or meat or milk from livestock raised in the decontaminated area.

Scenario B (a likely future use scenario) assumes residential use of the site. It is assumed that, at some time in the future, the industrial activities at the site will be discontinued and that the whole site will be transformed into a residential area. Under this scenario, in one year a hypothetical resident is assumed to spend $50 \%$ of the time indoors in the decontaminated area; $25 \%$ of the time outdoors in the decontaminated area; and $25 \%$ of the time away from the site. The resident is assumed to ingest plant foods grown in the garden. All water used by the resident for drinking, household purposes, and irrigation is

TABLE 1 Summary of Pathways for Scenarios A, B, and C at the Former Alba Craft Laboratory Site

\begin{tabular}{|c|c|c|c|}
\hline Pathway & Scenario $A^{a}$ & Scenario $\mathrm{B}^{\mathrm{b}}$ & Scenario $\mathrm{C}^{\mathrm{c}}$ \\
\hline External exposure & Yes & Yes & Yes \\
\hline Inhalation & Yes & Yes & Yes \\
\hline Radon & Yes & Yes & Yes \\
\hline Ingestion of plant foods & No & Yes & Yes \\
\hline Ingestion of meat & No & No & Yes \\
\hline Ingestion of milk & No & No & Yes \\
\hline Ingestion of fish & No & No & Yes \\
\hline Ingestion of soil & Yes & Yes & Yes \\
\hline Ingestion of water & No & No & Yes \\
\hline \multicolumn{4}{|l|}{ a Industrial worker. } \\
\hline \multicolumn{4}{|c|}{$\begin{array}{l}\text { Resident: water used for drinking, household purposes, and } \\
\text { irrigation is assumed to be from uncontaminated municipal } \\
\text { sources. }\end{array}$} \\
\hline \multicolumn{4}{|c|}{$\begin{array}{l}\text { Resident: water used for drinking, household purposes, livestock } \\
\text { watering, and irrigation is assumed to be from an on-site well. }\end{array}$} \\
\hline
\end{tabular}


from municipal sources that are not radioactively contaminated. For this scenario, it is assumed that no livestock is raised for the production of meat and milk and that no pond is present on-site to provide fish and other aquatic food.

Scenario C (a plausible but unlikely future use scenario) is similar to Scenario $B$, in which the resident is assumed to ingest plant foods grown in the garden. However, under Scenario $\mathrm{C}$, the resident is assumed to also ingest meat and milk from livestock fed with forage grown on-site and to catch and consume fish and other aquatic organisms from an on-site pond. For this scenario, the groundwater drawn from a well located on-site is the only water source for drinking, household purposes, livestock watering, and irrigation.

The RESRAD computer code (Yu et al. 1993) was used to calculate the potential radiation doses for the hypothetical future industrial worker and resident on the basis of the following assumptions:

- During one year, the industrial worker (Scenario A) spends 1,500 hours (17\%) outdoors at the site, 500 hours $(6 \%)$ indoors at the site, and 6,760 hours $(77 \%)$ away from the decontaminated area. During one year, the resident (Scenarios B and C) spends 4,380 hours (50\%) indoors, 2,190 hours $(25 \%)$ outdoors in the decontaminated area, and 2,190 hours (25\%) away from the site.

- The walls, floor, and foundation of the house or office building reduce external exposure by $30 \%$; the indoor dust level is $40 \%$ of the outdoor dust level (Yu et al. 1993).

- The depth of the house or building foundation is $1 \mathrm{~m}$ below ground surface, with an effective radon diffusion coefficient of $2 \times 10^{-8} \mathrm{~m}^{2} / \mathrm{s}$.

- The size of the decontaminated area is sufficiently large that $10 \%$ and $50 \%$ of the plant food diet consumed by the resident for Scenarios B and $\mathrm{C}$, respectively, is grown in a garden in the decontaminated area. The industrial worker does not consume these plant foods.

- The size of the decontaminated area is large enough to produce $15 \%$ of the forage used to feed livestock for meat and milk consumed by the resident in Scenario C. The industrial worker and the resident in Scenario B do not consume these animal products.

- For Scenario C, $50 \%$ of the fish and other aquatic food consumed by the resident is obtained from an on-site pond.

- The current supply of water for the industrial building and the nearby residential areas is from uncontaminated municipal sources. However, for the plausible but unlikely scenario (Scenario C), the source of water 
for drinking, household purposes, livestock watering, and irrigation purposes is assumed to be from an on-site well.

- After remedial action, no cover material is placed over the decontaminated area.

- No erosion of the contaminated material occurs.

- The thickness of the contaminated zone is based on conservative average values from ORNL measurements (Murray et al. 1993). The area surrounding the former Alba Craft Laboratory site $\left(3,000 \mathrm{~m}^{2}\right)$ is assumed to be homogeneously contaminated to an average depth of $0.5 \mathrm{~m}$. 


\section{DOSE/SOURCE CONCENTRATION RATIOS}

The RESRAD computer code, version 5.03 (Yu et al. 1993), was used to calculate the dose/source concentration ratio $D S R_{i p}(t)$ for uranium isotope $i$ and pathway $p$ at time $t$ after remedial action. The time frame considered in this analysis was 1,000 years. Radioactive decay and ingrowth were considered in deriving the dose/source concentration ratios. The various parameters used in the RESRAD code for this analysis are listed in the Appendix. The calculated maximum dose/source concentration ratios for all pathways are presented in Tables 2, 3, and 4 for Scenarios A, B, and C, respectively. For Scenarios A and B, the maximum dose/source concentration ratios would occur at time zero (immediately after remedial action); for Scenario $\mathrm{C}$, the maximum dose/source concentration ratio would occur 275 years following remedial action. The primary pathways for Scenarios A and B are inhalation and external exposure; for Scenario $\mathrm{C}$, the dominant pathway is ingestion of water. is,

The summation of $D S R_{i p}(t)$ for all pathways $p$ is the $D S R_{i}(t)$ for the $i$ th isotope; that

$$
D S R_{i}(t)=\sum_{p} D S R_{i p}(t)
$$

The total dose/source concentration ratio for total uranium can be calculated as

$$
\operatorname{DSR}(t)=\sum_{i} W_{i} \operatorname{DSR}_{i}(t),
$$

where $W_{i}$ is the existing activity concentration fraction at the site for uranium-234, uranium-235, and uranium-238.

For this analysis, $W_{i}$ is assumed to represent the natural activity concentration ratios of $1 / 2.046,1 / 2.046$, and $0.046 / 2.046$ for uranium-238, uranium-234, and uranium-235, respectively. The total dose/source concentration ratios for single nuclides and total uranium are provided in Table 5. These ratios were used to determine the allowable residual radioactivity for uranium at the former Alba Craft Laboratory site.

Uncertainty in the derivation of dose/source concentration ratios arises from the distribution of possible input parameter values as well as uncertainty in the conceptual model used to represent the site. Depending on the scenario, different parameters affect the resuits in each case. For Scenarios A and B, the inhalation and external exposure pathways contribute almost equally to most of the dose. Therefore, uncertainty in parameters affecting these pathways, such as the thickness of the contaminated zone and mass loading of dust in the air, will affect the results more than parameters affecting other pathways. In addition, doses will depend strongly on the choice of occupancy factors selected for these two scenarios. Because the maximum dose occurs at time zero, uncertainties in parameters that affect the leaching of radionuclides from the contaminated zone do not affect the results. However, the 
TABLE 2 Maximum Dose/Source Concentration Ratios for Scenario A (Industrial Worker) at the Former Alba Craft Laboratory Site

\begin{tabular}{lccc}
\hline & \multicolumn{3}{c}{ Maximum Dose/Source Concentration Ratio } \\
& \multicolumn{3}{c}{$(\mathrm{mrem} / \mathrm{yr}) /(\mathrm{pCi} / \mathrm{g})$} \\
\cline { 2 - 4 } \multicolumn{1}{c}{ Pathway } & Uranium-234 & Uranium-235 & Uranium-238 \\
\hline External exposure & $3.0 \times 10^{-4}$ & $1.9 \times 10^{-1}$ & $2.8 \times 10^{-2}$ \\
Inhalation & $2.0 \times 10^{-2}$ & $1.9 \times 10^{-2}$ & $1.9 \times 10^{-2}$ \\
Radon & 0 & 0 & 0 \\
Ingestion of soil & $1.8 \times 10^{-3}$ & $1.8 \times 10^{-3}$ & $1.8 \times 10^{-3}$ \\
\hline
\end{tabular}

a Maximum dose/source concentration ratios would occur at time zero (immediately following remedial action); all values are reported to two significant figures.

TABLE 3 Maximum Dose/Source Concentration Ratios for Scenario B (Resident: Municipal Water Supply) at the Former Alba Craft Laboratory Site

Maximum Dose/Source Concentration Ratio ${ }^{a}$ $(\mathrm{mrem} / \mathrm{yr}) /(\mathrm{pCi} / \mathrm{g})$

\begin{tabular}{llcc} 
& \multicolumn{3}{c}{ Maximum $\begin{array}{c}\text { Dose/Source Concentration Ratio } \\
(\mathrm{mrem} / \mathrm{yr}) /(\mathrm{pCi} / \mathrm{g})\end{array}$} \\
\cline { 2 - 4 } \multicolumn{1}{c}{ Pathway } & Uranium-234 & Uranium-235 & Uranium-238 \\
\hline External exposure & $8.5 \times 10^{-4}$ & $5.5 \times 10^{-1}$ & $7.8 \times 10^{-2}$ \\
Inhalation & $4.7 \times 10^{-2}$ & $4.3 \times 10^{-2}$ & $4.3 \times 10^{-2}$ \\
Radon & 0 & 0 & 0 \\
Ingestion of plant foods & $6.3 \times 10^{-3}$ & $6.1 \times 10^{-3}$ & $6.1 \times 10^{-3}$ \\
Ingestion of soil & $4.3 \times 10^{-3}$ & $4.1 \times 10^{-3}$ & $4.1 \times 10^{-3}$ \\
\hline
\end{tabular}

a Maximum dose/source concentration ratios would occur at time zero (immediately following remedial action); all values are reported to two significant figures. 
TABLE 4 Maximum Dose/Source Concentration Ratios

for Scenario C (Resident: On-Site Well Water)

at the Former Alba Craft Laboratory Site

\begin{tabular}{llll}
\hline & \multicolumn{3}{c}{ Maximum Dose/Source Concentration Ratio } \\
& \multicolumn{3}{c}{$(\mathrm{mrem} / \mathrm{yr}) /(\mathrm{pCi} / \mathrm{g})$} \\
\cline { 2 - 4 } \multicolumn{1}{c}{ Pathway } & Uranium-234 & Uranium-235 & Uranium-238 \\
\cline { 2 - 4 } & $3.2 \times 10^{-4}$ & $2.3 \times 10^{-2}$ & $3.2 \times 10^{-3}$ \\
External exposure & $2.0 \times 10^{-3}$ & $2.2 \times 10^{-3}$ & $1.8 \times 10^{-3}$ \\
Inhalation & $9.5 \times 10^{-6}$ & 0 & $1.9 \times 10^{-9}$ \\
Radon & $2.4 \times 10^{-2}$ & $4.1 \times 10^{-2}$ & $2.3 \times 10^{-2}$ \\
Ingestion of plant foods & $3.4 \times 10^{-4}$ & $1.6 \times 10^{-3}$ & $3.3 \times 10^{-4}$ \\
Ingestion of meat & $1.3 \times 10^{-3}$ & $1.3 \times 10^{-3}$ & $1.2 \times 10^{-3}$ \\
Ingestion of milk & $8.2 \times 10^{-4}$ & $4.6 \times 10^{-3}$ & $7.9 \times 10^{-4}$ \\
Ingestion of fish & $1.9 \times 10^{-4}$ & $2.5 \times 10^{-4}$ & $1.7 \times 10^{-4}$ \\
Ingestion of soil & $2.9 \times 10^{-1}$ & $5.0 \times 10^{-1}$ & $2.8 \times 10^{-1}$ \\
Ingestion of water & & & \\
\hline
\end{tabular}

a Maximum dose/source concentration ratios would occur at 275 years following remedial action; all values are reported to two significant figures.

TABLE 5 Total Dose/Source Concentration Ratios for Uranium at the Former Alba Craft Laboratory Site

\begin{tabular}{lccc}
\hline & \multicolumn{3}{c}{$\begin{array}{c}\text { Maximum Dose/Source Concentration Ratio } \\
(\mathrm{mrem} / \mathrm{yr}) /(\mathrm{pCi} / \mathrm{g})\end{array}$} \\
\cline { 2 - 4 } Radionuclide & Scenario $\mathrm{A}^{\mathrm{b}}$ & Scenario B $^{\mathrm{c}}$ & Scenario C $^{\mathrm{d}}$ \\
\hline & & $5.8 \times 10^{-2}$ & $3.2 \times 10^{-1}$ \\
Uranium-234 & $2.2 \times 10^{-2}$ & $6.1 \times 10^{-1}$ & $5.7 \times 10^{-1}$ \\
Uranium-235 & $2.1 \times 10^{-1}$ & $1.3 \times 10^{-1}$ & $3.1 \times 10^{-1}$ \\
Uranium-238 & $4.8 \times 10^{-2}$ & $1.1 \times 10^{-1}$ & $3.2 \times 10^{-1}$ \\
\hline Total uranium & $3.9 \times 10^{-2}$ & $1.9 \times 1$ \\
\hline
\end{tabular}

a All values are reported to two significant figures.

b Industrial worker (current use scenario).

c Resident: water used for drinking, household purposes, and irrigation is assumed to be from uncontaminated municipal sources (likely future use scenario).

d Resident: water used for drinking, household purposes, livestock watering, and irrigation is assumed to be from an on-site well (unlikely future use scenario). 
opposite is true for Scenario $\mathrm{C}$, in which almost all of the dose is contributed by the drinking water pathway; in this case, the resulting dose will be affected by uncertainties in soil properties, meteorological parameters, distribution coefficients, water consumption rate, and other parameters affecting the leaching and transport of radionuclides. For Scenario C, the dose is almost linearly proportional to the assumed thickness of the contaminated zone as well as the drinking water consumption rate, and the choice of occupancy factors does not significantly affect the results. Laboratory analysis of the uncontaminated soil samples obtained from the site indicated that the distribution coefficient for uranium is on the order of $70,000 \mathrm{~cm}^{3} / \mathrm{g}$ (Orlandini 1994). This value is much higher than the conservative values, 50 and $5 \mathrm{~cm}^{3} / \mathrm{g}$, assumed in the analysis.

The RESRAD default values have been used if no site-specific data were available. These default values are based on national average or reasonable maximum values. In addition, the contaminated zone thickness of $0.5 \mathrm{~m}$ that was selected to derive the dose/source concentration ratios is based on the assumption that the soil is uniformly contaminated to that depth. In reality, most of the contamination occurs in the top $15 \mathrm{~cm}$ of soil and is not dispersed uniformly throughout the site. Therefore, the calculated dose/source ratios are conservative. 


\section{RESIDUAL RADIOACTIVE MATERIAL GUIDELINES}

The residual radioactive material guideline is the concentration of residual radioactive material that can remain in a decontaminated area and still allow use of the area without radiological restrictions. Given a dose limit of $H_{E L}$ for an individual, the residual radioactive material guideline $G$ for uranium at the former Alba Craft Laboratory site can be calculated as

$$
G=H_{E L} / D S R,
$$

where $D S R$ is the total dose/source concentration ratio listed in Table 5. The dose limit, $H_{E L}$, used to derive the residual radioactive material guideline is $30 \mathrm{mrem} / \mathrm{yr}$ for the current use and likely future use scenarios and $100 \mathrm{mrem} / \mathrm{yr}$ for all other plausible future use scenarios ( $Y u$ et al. 1993). The calculated residual radioactive material guidelines for both single radionuclides (uranium-234, uranium-235, and uranium-238) and total uranium are presented in Table 6.

In calculating the total uranium guidelines (reported to two significant figures), it was assumed that the activity concentration ratio of uranium-238, uranium-234, and uranium-235 is 1:1:0.046. The derived guidelines for total uranium are 770,280 , and $310 \mathrm{pCi} / \mathrm{g}$ for Scenarios A, B, and C, respectively. If uranium-238 is measured as the

TABLE 6 Residual Radioactive Material Guidelines for the Former Alba Craft Laboratory Site

\begin{tabular}{lccc}
\hline & \multicolumn{3}{c}{${\text { Guideline }(\mathrm{pCi} / \mathrm{g})^{\mathrm{a}}}$} \\
\cline { 2 - 4 } Radionuclide & Scenario A $^{\mathrm{b}}$ & Scenario $^{\mathrm{c}}$ & Scenario C $^{\mathrm{d}}$ \\
\hline & & & \\
Uranium-234 & 1,400 & 520 & 310 \\
Uranium-235 & 140 & 50 & 180 \\
Uranium-238 & 630 & 230 & 320 \\
Total uranium & 770 & 280 & 310 \\
\hline
\end{tabular}

a All values are reported to two significant figures.

b Industrial worker (current use scenario: dose constraint = $30 \mathrm{mrem} / \mathrm{yr}$ ).

c Resident: water used for drinking, household purposes, and irrigation is assumed to be from uncontaminated municipal sources (likely future use scenario: dose constraint = $30 \mathrm{mrem} / \mathrm{yr}$ ).

d Resident: water used for drinking, household purposes, livestock watering, and irrigation is assumed to be from an on-site well (unlikely but plausible future use scenario: dose limit $=100 \mathrm{mrem} / \mathrm{yr}$ ). 
indicator radionuclide, the uranium-238 limits for total uranium can be calculated by dividing the total uranium guidelines by 2.046 . The resulting uranium-238 limits are 380,140 , and $150 \mathrm{pCi} / \mathrm{g}$ for Scenarios A, B, and C, respectively.

When implementing the derived radionuclide guidelines for decontamination of a site, the law of sum of fractions applies. That is, the summation of the radionuclide concentrations $S_{i}$ remaining on-site (averaged over an area of $100 \mathrm{~m}^{2}$ and a depth of $15 \mathrm{~cm}$ ) divided by their guidelines $G_{i}$ should not be greater than unity; that is,

$$
\sum_{i} S_{i} / G_{i} \leq 1
$$

The derived guidelines listed in Table 6 are for a large homogeneously contaminated area. For a small, isolated area of contamination - a hot spot - the allowable concentration that can remain on-site may be higher than the homogeneous guideline, depending on the size of the contaminated area and in accordance with the ranges given in Table 7 .

TABLE 7 Ranges for Hot Spot Multiplication Factors

\begin{tabular}{cc}
\hline Range $\left(\mathrm{m}^{2}\right)$ & $\begin{array}{c}\text { Factor } \\
\text { (multiple of } \\
\text { authorized limit) }\end{array}$ \\
\hline$<1$ & $10^{\mathrm{a}}$ \\
$1-<3$ & 6 \\
$3-<10$ & 3 \\
$10-25$ & 2 \\
\hline
\end{tabular}

a Areas less than $1 \mathrm{~m}^{2}$ are to be averaged over a $1-\mathrm{m}^{2}$ area, and that average shall not exceed 10 times the authorized limit.

Source: Yu et al. (1993). 


\section{REFERENCES}

International Commission on Radiological Protection, 1991, 1990 Recommendations of the International Commission on Radiological Protection, ICRP Publ. 60, Annals of the ICRP 21(1-3).

Murray, M.E., et al., 1993, Results of the Radiological Survey at the Former Alba Craft Laboratory Site Properties, Oxford, Ohio (OXO001), ORNL/RASA-92/14, prepared by Oak Ridge National Laboratory, Health and Safety Research Division, Oak Ridge, Tenn., for U.S. Department of Energy, Office of Environmental Restoration, March.

Orlandini, K.A., 1994, "Distribution Coefficient of Uranium between an Ohio Soil and Rain Water," interoffice memorandum from K.A. Orlandini (Environmental Research Division) to C. Yu (Environmental Assessment Division), Argonne National Laboratory, Argonne, Ill., Jan. 19.

Smith, B.S., 1982, Occurrence and Quality of Ground Water in the Oxford-Morning Sun Area, Ohio, Master's thesis, Miami University, Oxford, Ohio.

IJ.S. Department of Energy, 1990, Radiation Protection of the Public and Environment, DOE Order 5400.5, Feb. 8.

Yu, C., et al., 1993, Manual for Implementing Residual Radioactive Material Guidelines Using RESRAD, Version 5.0, ANL/EAD/LD-2, prepared by Argonne National Laboratory, Argonne, Ill., for U.S. Department of Energy, Office of Environmental Restoration, Sept. 


\section{APPENDIX:}

\section{SCENARIOS AND PARAMETERS USED FOR THE ANALYSIS OF THE FORMER ALBA CRAFT LABORATORY SITE}

The following exposure scenarios were analyzed for the former Alba Craft Laboratory Site in Oxford, Ohio:

- Scenario A: Industrial Use of the Site. A hypothetical person is assumed to work in the area of the site.

- Scenario B: Residential Use of the Site - Municipal Water Supply. A hypothetical resident is assumed to live in the decontaminated area and to use an uncontaminated municipal water supply for drinking, household purposes, and irrigation. The resident is assumed to ingest plant foods grown on-site; however, no livestock is raised for the production of meat and milk, and no pond is present on-site to provide fish and other aquatic food.

- Scenario C: Residential Use of the Site - On-Site Well Water. A hypothetical resident is assumed to live in the decontaminated area and to use water from an on-site well for drinking, household purposes, livestock watering, and irrigation. The resident is assumed to ingest plant foods grown in the garden and meat and milk from livestock fed with forage grown on-site. The resident is assumed to catch and consume fish and other aquatic organisms from an on-site pond.

The parametric values used in the RESRAD code for the analysis of the former Alba Craft Laboratory site are listed in Table A.1. All parametric values are reported at up to three significant figures. Some parameters are specific to the former Alba Craft Laboratory site; other values are generic. 
TABLE A.1 Parameters Used in the RESRAD Computer Code for the Analysis of the Former Alba Craft Laboratory Site

\begin{tabular}{|c|c|c|c|c|}
\hline \multirow[b]{2}{*}{ Parameter } & \multirow[b]{2}{*}{ Unit } & \multicolumn{3}{|c|}{ Value } \\
\hline & & Scenario A & Scenario B & Scenario C \\
\hline Area of contaminated zone $e^{a}$ & $\mathrm{~m}^{2}$ & 3,000 & 3,000 & 3,000 \\
\hline Thickness of contaminated zone $\mathrm{e}^{\mathrm{a}}$ & $\mathrm{m}$ & 0.5 & 0.5 & 0.5 \\
\hline Length parallel to aquifer flow ${ }^{\mathrm{a}}$ & $\mathbf{m}$ & Not used & Not used & 55 \\
\hline Basic radiation dose limit ${ }^{a, b}$ & mrem/yr & 30 & 30 & 100 \\
\hline Cover depth ${ }^{\mathrm{a}}$ & $\mathrm{m}$ & 0 & 0 & 0 \\
\hline \multicolumn{5}{|l|}{ Contaminated zone: } \\
\hline Density ${ }^{b}$ & $\mathrm{~g} / \mathrm{cm}^{3}$ & 1.5 & 1.5 & 1.5 \\
\hline Erosion rate $^{a}$ & $\mathrm{~m} / \mathrm{yr}$ & 0 & 0 & 0 \\
\hline Total porosity & $-\mathrm{c}$ & 0.4 & 0.4 & 0.4 \\
\hline Effective porosity ${ }^{\mathrm{b}}$ & $-c$ & 0.2 & 0.2 & 0.2 \\
\hline Hydraulic conductivity ${ }^{b}$ & $\mathrm{~m} / \mathrm{yr}$ & 10 & 10 & 10 \\
\hline Soil-specific b parameter ${ }^{b}$ & $-c$ & 5.3 & 5.3 & 5.3 \\
\hline Evapotranspiration coefficient ${ }^{a}$ & $-c$ & 0.57 & 0.57 & 0.57 \\
\hline Precipitation $^{\mathrm{a}}$ & $\mathrm{m} / \mathrm{yr}$ & 1.03 & 1.03 & 1.03 \\
\hline Irrigation $^{\mathrm{b}}$ & $\mathrm{m} / \mathrm{yr}$ & 0.2 & 0.2 & 0.2 \\
\hline Irrigation mode ${ }^{b}$ & c & Overhead & Overhead & Overhead \\
\hline Runoff coefficient ${ }^{\mathrm{a}}$ & $-c$ & 0.21 & 0.21 & 0.21 \\
\hline Watershed area for nearby pond ${ }^{a, b}$ & $\mathrm{~m}^{2}$ & Not used & Not used & $1,000,000$ \\
\hline \multicolumn{5}{|l|}{ Saturated zone: } \\
\hline Density ${ }^{a, b}$ & $\mathrm{~g} / \mathrm{cm}^{3}$ & Not used & Not used & 1.5 \\
\hline Total porosity & $-c$ & Not used & Not used & 0.34 \\
\hline Effective porosity ${ }^{a}$ & $-\mathrm{c}$ & Not used & Not used & 0.28 \\
\hline Hydraulic conductivity ${ }^{a}$ & $\mathrm{~m} / \mathrm{yr}$ & Not used & Not used & 5,000 \\
\hline Hydraulic gradient ${ }^{\mathrm{a}, \mathrm{b}}$ & c & Not used & Not used & 0.02 \\
\hline Soil-specific b parameter ${ }^{a}$ & $-c$ & Not used & Not used & Not used \\
\hline Water table drop rate ${ }^{a}$ & $\mathrm{~m} / \mathrm{yr}$ & Not used & Not used & 0 \\
\hline Well pump intake depth (below water table) ${ }^{\mathbf{a}}$ & m & Not used & Not used & 2.1 \\
\hline $\begin{array}{l}\text { Model: nondispersion (ND) or mass } \\
\text { balance }(\mathrm{MB})^{\mathrm{b}}\end{array}$ & $-c$ & Not used & Not used & ND \\
\hline Individual use of groundwater ${ }^{a}$ & $\mathrm{~m}^{3} / \mathrm{yr}$ & Not used & Not used & Not used \\
\hline Number of unsaturated zone strata ${ }^{a}$ & $-c$ & Not used & Not used & 2 \\
\hline \multicolumn{5}{|l|}{ Unsaturated zone 1 : } \\
\hline Thickness $^{\mathrm{a}}$ & $\mathrm{m}$ & Not used & Not used & 1.7 \\
\hline Soil density ${ }^{a, b}$ & $\mathrm{~g} / \mathrm{cm}^{3}$ & Not used & Not used & 1.5 \\
\hline Total porosity ${ }^{\mathrm{a}, \mathrm{b}}$ & $-c$ & Not used & Not used & 0.4 \\
\hline Effective porosity ${ }^{\mathrm{a}, \mathrm{b}}$ &. $\mathrm{c}$ & Not used & Not used & 0.2 \\
\hline Soil-specific b parameter ${ }^{a, b}$ & $-\mathbf{c}$ & Not used & Not used & 5.3 \\
\hline Hydraulic conductivity ${ }^{\mathrm{b}}$ & $\mathrm{m} / \mathrm{yr}$ & Not used & Not used & 10 \\
\hline \multicolumn{5}{|l|}{ Unsaturated zone 2 : } \\
\hline Thickness ${ }^{\mathrm{a}}$ & m & Not used & Not used & 4 \\
\hline Soil density ${ }^{a, b}$ & $\mathrm{~g} / \mathrm{cm}^{3}$ & Not used & Not used & 1.5 \\
\hline Total porosity ${ }^{\mathrm{a}}$ & $-c$ & Not used & Not used & 0.42 \\
\hline Effective porosity ${ }^{a}$ & $-c$ & Not used & Not used & 0.06 \\
\hline Soil-specific b parameter ${ }^{a}$ & $-\mathrm{c}$ & Not used & Not used & 11.4 \\
\hline Hydraulic conductivity ${ }^{\mathrm{a}}$ & $\mathrm{m} / \mathrm{yr}$ & Not used & Not used & 40 \\
\hline Distribution coefficient $^{\mathrm{a}, \mathrm{b}}$ : & $\mathrm{cm}^{3} / \mathrm{g}$ & & & \\
\hline \multicolumn{5}{|l|}{ Contaminated zone } \\
\hline Uranium-234 & & Not used & Not used & 50 \\
\hline Uranium-235 & & Not used & Not used & 50 \\
\hline Uranium-238 & & Not used & Not used & 50 \\
\hline Actinium-227 & & Not used & Not used & 20 \\
\hline Protactinium-231 & & Not used & Not used & 50 \\
\hline Lead-210 & & Not used & Not used & 100 \\
\hline Radium-226 & & Not used & Not used & 70 \\
\hline Thorium-230 & & Not used & Not used & 60,000 \\
\hline
\end{tabular}


TABLE A.1 (Cont.)

\begin{tabular}{|c|c|c|c|c|}
\hline \multirow[b]{2}{*}{ Parameter } & \multirow[b]{2}{*}{ Unit } & \multicolumn{3}{|c|}{ Value } \\
\hline & & Scenario A & Scenario B & Scenario C \\
\hline $\begin{array}{l}\text { Distribution coefficient } t^{\mathrm{a}, \mathrm{b}} \text { (cont.): } \\
\text { Unsaturated zone } 1\end{array}$ & & & & \\
\hline Uranium-234 & & Not used & Not used & 50 \\
\hline Uranium-235 & & Not used & Not used & 50 \\
\hline Uranium-238 & & Not used & Not used & 50 \\
\hline Actinium-227 & & Not used & Not used & 20 \\
\hline Protactinium-231 & & Not used & Not used & 50 \\
\hline Lead-210 & & Not used & Not used & 100 \\
\hline Radium-226 & & Not used & Not used & 70 \\
\hline Thorium-230 & & Not used & Not used & 60,000 \\
\hline \multicolumn{5}{|l|}{ Unsaturated zone 2} \\
\hline Uranium-234 & & Not used & Not used & 50 \\
\hline Uranium-235 & & Not used & Not used & 50 \\
\hline Uranium-238 & & Not used & Not used & 50 \\
\hline Actinium-227 & & Not used & Not used & 20 \\
\hline Protactinium-231 & & Not used & Not used & 50 \\
\hline Lead-210 & & Not used & Not used & 100 \\
\hline Radium-226 & & Not used & Not used & 70 \\
\hline Thorium-230 & & Not used & Not used & 60,000 \\
\hline \multicolumn{5}{|l|}{ Saturated zone } \\
\hline Uranium-234 & & Not used & Not used & 5 \\
\hline Uranium-235 & & Not used & Not used & 5 \\
\hline Uranium-238 & & Not used & Not used & 5 \\
\hline Actinium-227 & & Not used & Not used & 2 \\
\hline Protactinium-231 & & Not used & Not used & 5 \\
\hline Lead-210 & & Not used & Not used & 10 \\
\hline Radium-226 & & Not used & Not used & 7 \\
\hline Thorium-230 & & Not used & Not used & 6,000 \\
\hline Inhalation rate b $^{\mathrm{b}}$ & $\mathrm{m}^{3} / \mathrm{yr}$ & 8,400 & 8,400 & 8,400 \\
\hline Mass loading for inhalation ${ }^{a}$ & $\mathrm{~g} / \mathrm{m}^{3}$ & 0.0001 & 0.0001 & 0.0001 \\
\hline Shielding factor, inhalation ${ }^{b}$ & c & 0.4 & 0.4 & 0.4 \\
\hline Shielding factor, external gamma ${ }^{b}$ & $\therefore$ c & 0.7 & 0.7 & 0.7 \\
\hline Fraction of time indoors $\mathrm{s}^{\mathrm{a}, \mathrm{b}}$ & c & 0.057 & 0.5 & 0.5 \\
\hline Fraction of time outdoors ${ }^{a, b}$ & 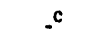 & 0.171 & 0.25 & 0.25 \\
\hline Shape factor, external gamma & $-c$ & 1 & 1 & 1 \\
\hline Dilution length for airborne dust, inhalation ${ }^{b}$ & $\mathbf{m}$ & 3 & 3 & 3 \\
\hline \multicolumn{5}{|l|}{ Food consumption: } \\
\hline Fruits, vegetables, and grain ${ }^{a, b}$ & $\mathrm{~kg} / \mathrm{yr}$ & Not used & 160 & 160 \\
\hline Leafy vegetables ${ }^{a, b}$ & $\mathrm{~kg} / \mathrm{yr}$ & Not used & 14 & 14 \\
\hline Milk $^{\mathrm{a}, \mathrm{b}}$ & $\mathrm{L} / \mathrm{yr}$ & Not used & Not used & 92 \\
\hline Meat and poultry ${ }^{a, b}$ & $\mathrm{~kg} / \mathrm{yr}$ & Not used & Not used & 63 \\
\hline Fish $^{\mathrm{a}}$ & $\mathrm{kg} / \mathrm{yr}$ & Not used & Not used & 5.4 \\
\hline Other aquatic food ${ }^{a}$ & $\mathrm{~kg} / \mathrm{yr}$ & Not used & Not used & 0.9 \\
\hline Soil ingestion ${ }^{a, b}$ & $\mathrm{~g} / \mathrm{yr}$ & 36.5 & 36.5 & 36.5 \\
\hline Drinking water intake $\mathrm{e}^{\mathrm{a}, \mathrm{b}}$ & $\mathrm{L} / \mathrm{yr}$ & Not used & Not used & 510 \\
\hline \multicolumn{5}{|l|}{ Contaminated fraction of food and water: } \\
\hline Drinking water ${ }^{\mathrm{a}, \mathrm{b}}$ & & Not used & 0 & 1.0 \\
\hline Household water $a, b$ & & Not used & 0 & 1.0 \\
\hline Livestock water ${ }^{a, b}$ & & Not used & Not used & 1.0 \\
\hline Irrigation water ${ }^{a, b}$ & & Not used & 0 & 1.0 \\
\hline Aquatic food $\mathrm{d}^{\mathrm{a}, \mathrm{b}}$ & & Not used & Not used & 0.5 \\
\hline Plant food ${ }^{a}$ & & Not used & $0.1^{\mathrm{a}}$ & $0.5^{\mathrm{d}}$ \\
\hline Meat $^{\mathrm{a}}$ & & Not used & Not used & $0.15^{\mathrm{d}}$ \\
\hline Milk $^{a}$ & & Not used & Not used & $0.15^{\mathrm{d}}$ \\
\hline Livestock fodder intake for meat ${ }^{a, b}$ & $\mathrm{~kg} / \mathrm{d}$ & Not used & Not used & 68 \\
\hline Livestock fodder intake for milk ${ }^{a, b}$ & $\mathrm{~kg} / \mathrm{d}$ & Not used & Not used & 55 \\
\hline
\end{tabular}


TABLE A.1 (Cont.)

\begin{tabular}{|c|c|c|c|c|}
\hline \multirow[b]{2}{*}{ Parameter } & \multirow[b]{2}{*}{ Unit } & \multicolumn{3}{|c|}{ Value } \\
\hline & & Scenario A & Scenario B & Scenario C \\
\hline Livestock water intake for meat ${ }^{a, b}$ & $\mathrm{~L} / \mathrm{d}$ & Not used & Not used & 50 \\
\hline Livestock water intake for milk ${ }^{a, b}$ & $\mathrm{~L} / \mathrm{d}$ & Not used & Not used & 160 \\
\hline Livestock soil intake $\mathrm{e}^{\mathrm{a}, \mathrm{b}}$ & $\mathrm{kg} / \mathrm{d}$ & Not used & Not used & 0.5 \\
\hline Mass loading for foliar deposition ${ }^{a, b}$ & $\mathrm{~g} / \mathrm{m}^{3}$ & Not used & 0.0001 & 0.0001 \\
\hline Depth of soil mixing layer & $\mathbf{m}$ & 0.15 & 0.15 & 0.15 \\
\hline Depth of roots ${ }^{a, b}$ & $\mathbf{m}$ & Not used & 0.9 & 0.9 \\
\hline & $-c$ & \multicolumn{2}{|c|}{ Groundwater fractional usage (balance } & \\
\hline Drinking water ${ }^{\mathrm{a}, \mathrm{b}}$ & & Not used & Not used & 1.0 \\
\hline Household water ${ }^{a, b}$ & & Not used & Not used & 1.0 \\
\hline Livestock water $r^{a, b}$ & & Not used & Not used & 1.0 \\
\hline Irrigation ${ }^{a, b}$ & & Not used & Not used & 1.0 \\
\hline Total porosity of the cover material ${ }^{\mathrm{a}}$ & $c^{c}$ & Not used & Not used & Not used \\
\hline $\begin{array}{l}\text { Total porosity of the house or building } \\
\text { foundation } b\end{array}$ & c & 0.1 & 0.1 & 0.1 \\
\hline $\begin{array}{l}\text { Volumetric water content of the cover } \\
\text { material }{ }^{\mathrm{a}}\end{array}$ & $\Omega^{c}$ & Not used & Not used & Not used \\
\hline Volumetric water content of the foundation ${ }^{b}$ & $-c$ & 0.03 & 0.03 & 0.03 \\
\hline \multicolumn{5}{|l|}{ Diffusion coefficient for radon gas: } \\
\hline In cover material ${ }^{\mathrm{a}}$ & & Not used & Not used & Not used \\
\hline In foundation material ${ }^{b}$ & & $3.0 \times 10^{-7}$ & $3.0 \times 10^{-7}$ & $3.0 \times 10^{-7}$ \\
\hline In contaminated zone soil ${ }^{\mathrm{b}}$ & & $2.0 \times 10^{-6}$ & $2.0 \times 10^{-6}$ & $2.0 \times 10^{-6}$ \\
\hline Emanating power of radon- $222^{b}$ & $-c$ & 0.25 & 0.25 & 0.25 \\
\hline Emanating power of radon $-220^{\mathrm{a}}$ &. $\mathrm{c}$ & Not used & Not used & Not used \\
\hline Radon vertical dimension of mixing ${ }^{b}$ & $\mathbf{m}$ & 2.0 & 2.0 & 2.0 \\
\hline Average annual wind speed ${ }^{b}$ & $\mathrm{~m} / \mathrm{s}$ & 2.0 & 2.0 & 2.0 \\
\hline Average building air exchange rate ${ }^{b}$ & $1 / h$ & 0.5 & 0.5 & 0.5 \\
\hline Height of building (room) ${ }^{\mathrm{b}}$ & m & 2.5 & 2.5 & 2.5 \\
\hline Building indoor area factor ${ }^{b}$ & c & 0 & 0 & 0 \\
\hline Bulk density of house or building foundation ${ }^{b}$ & $\mathrm{~g} / \mathrm{cm}^{3}$ & 2.4 & 2.4 & 2.4 \\
\hline Thickness of house or building foundation ${ }^{\mathrm{b}}$ & $\mathrm{m}$ & 0.15 & 0.15 & 0.15 \\
\hline Building depth below ground surface ${ }^{b}$ & m & 1.0 & 1.0 & 1.0 \\
\hline
\end{tabular}

a Values based on site specifications, scenario assumptions, or Yu et al. (1993).

b RESRAD default values.

c Parameter is dimensionless.

d Calculated with the RESRAD computer code. 

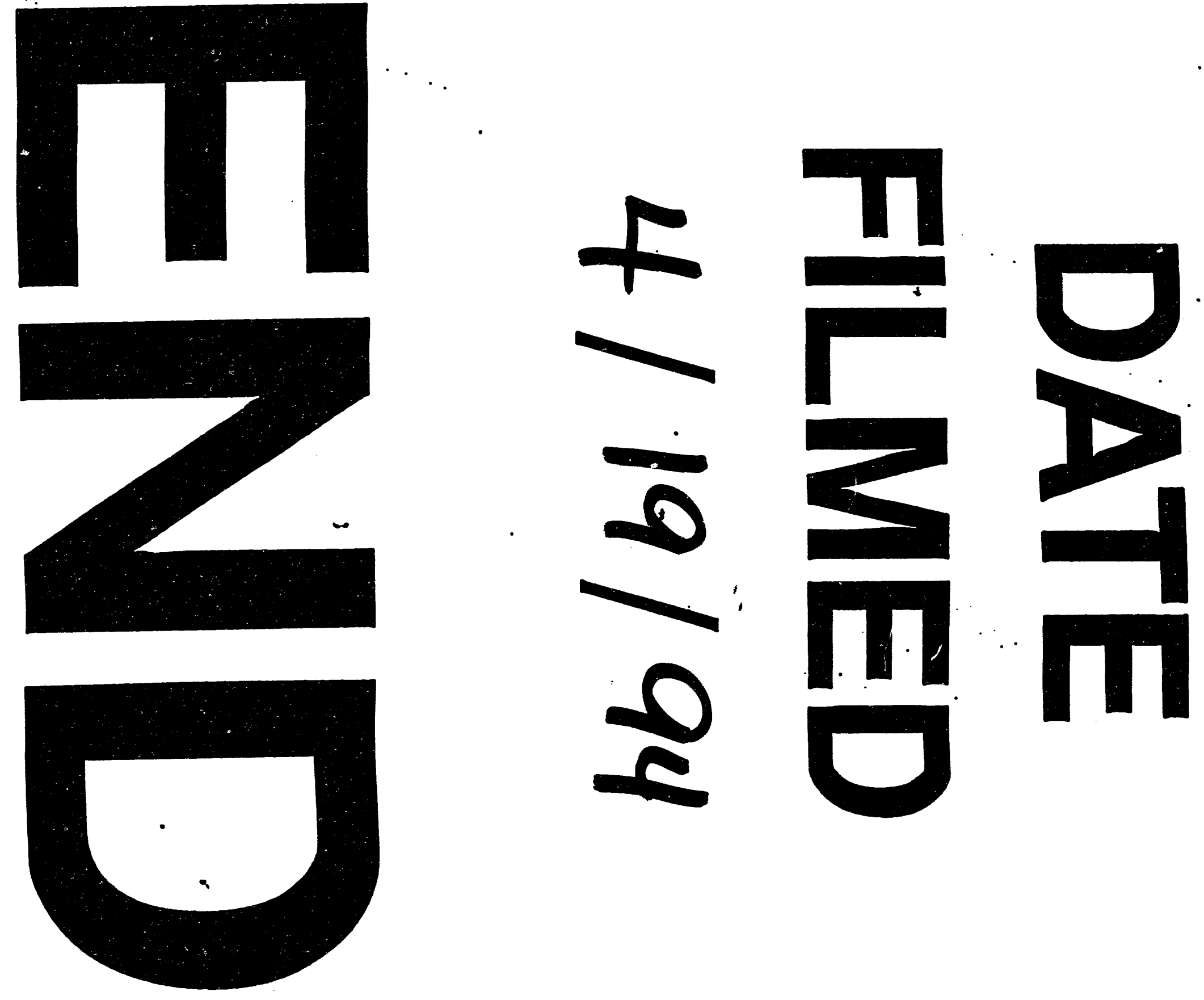
